\title{
Internationalization and the Need of Business Model Innovation - A Theoretical Approach
}

\author{
Moema Pereira Nunes ${ }^{1,+(D)}$ \\ ${ }^{1}$ Universidade FEEVALE, Novo Hamburgo, RS, Brazil \\ Fernanda Kalil Steinbruch 2,2(D) \\ ${ }^{2}$ Universidade FEEVALE, Novo Hamburgo, RS, Brazil
}

\section{ABSTRACT}

The global market can be considered a volatile environment and the internationalization of a firm through the adoption of any entry mode may lead to the need to innovate or adapt its business model (BM) to better fit specific contexts of international markets. Even though entry modes have been deeply investigated during the last decades, the relation of business model innovation (BMI) and entry modes is a new study subject. This article assumes that the internationalization process is a trigger for innovation, and it aims to answer what are the different possibilities of BMI generated through the entry modes. The concepts of $\mathrm{BM}, \mathrm{BMI}$, and its relationship with internationalization and entry modes are investigated in this paper. Based on the literature review, a theoretical model is proposed to relate entry modes and the need of business model innovation. We identified that little is known about the relation between these subjects and applied research is required.

Keywords: Internationalization. Entry Modes. Business Model. Business Model Innovation.

\section{INTRODUCTION}

The global market can be considered a volatile environment and the internationalization of a firm through the adoption of any entry mode represents a change in the way it operates. As argued by Schneider and Spieth (2013), the effects of an increasing globalization in the business environment have been identified as a driver of a firm's need to innovate its business model (BM) (Lee, Shin \& Park, 2012). A BM that efficiently supports a company's competitive advantage in one market, may be challenged in a different one. Therefore, the BM needs to be innovated or adapted to better fit specific contexts of international markets (Landau, Karna \& Sailer, 2016). In addition, a business model innovation (BMI) is a promising approach for firms to respond to changing sources of value creation in highly volatile environments (Pohle \& Chapman, 2006).

A BM is the way companies can commercialize new ideas and technologies, and as the same technology can be commercialized in two different ways, it can lead to two different outcomes (Chesbrough, 2010). Internally, it is motivated by the social capital of the company as it helps to achieve objectives, including apparent and potential resources and capabilities. Externally, it is motivated by market demand, 
technological advancement, and economic environment (Zhang, Zhao, \& Xu, 2015). The creation of value can go beyond the Schumpeterian innovation, the Porter's (re)configuration of the value chain, the formation of strategic networks among firms, and the exploitation of firm's core competences (Zoot, Amit \& Massa, 2011). It can be created through an innovative BM.

There is a current increase in the interest in $\mathrm{BM}$ and one of the main questions researchers have been trying to answer is how to innovate a BM. This interest opens a range of directions for further research in the field. Spieth, Schneckenberg and Ricart (2014) presented a set of future research directions. One of the topics listed by them is related to the antecedents for Business Model Innovation (BMI) and to the debate of whether volatile environments drive BMI of firms or vice versa. As argued by Chesbrough (2007), even a successful BM cannot be assured as permanent given its dynamic environment. The circumstances of the environment may 'force' a company to reinvent its BM, and the ability to do so represents a source of competitive advantage in turbulent environments (Hamel \& Valikangas, 2003). The ability to innovate a BM represents a way to respond to changing sources of value creation in volatile environments (Pohle \& Chapman, 2006).

Regarding the need for research on the processes and elements of BMI, Schneider and Spieth (2013) argue that there is a necessity to investigate what determines their specific contexts. The global environment can be considered a specific context for a research field. Despite the already identified lack of literature and even a specific demand for it (Demil et al, 2015), little is known, from an empirical perspective, about the adaptation of a BM to specific markets aside from Landau, Karna and Sailer's work (2016). Putting aside this gap, BMI involves creation or reinvention to support internationalization (Rask, 2014). Entry modes are ways to materialize company's internationalization process and each one implies in different needs of changes in a company's BM. Even though entry modes have been deeply investigated during the last decades, the relation between BMI and entry modes is a new subject of study. Landau, Karna and Sailer (2016) investigated a single case study of internationalization and BM but no special aspects of the entry mode were highlighted. Rask (2014) carried out a theoretical investigation in which entry modes were considered antecedents, but the consequences of each one of them in the BM was neglected. Based on this, it is relevant to inquire if the internationalization of a company through the adoption of different entry modes generates the need for BMI. Considering so, this research questions: What are the different possibilities of BMI generated through the entry modes for internationalization?

This article assumes that the internationalization process triggers innovation. However, the literature about BM has very few studies about this relation, as previously mentioned. Besides that, most of the research regarding BM are related to technology-based companies or start-ups (Chesbrough, 2010; Chesbrough \& Rosenbloom, 2002; Teece, 2010; Timers, 1998; Venkatraman \& Henderson, 1998). There is also a gap regarding studies about more traditional business and well-established firms (Chesbrough, 2010).

This article is a literature review and a proposed framework was developed based on the available literature about the researched topics. To analyze the contents, an integrative review was developed with the purpose to combine findings of different areas of knowledge. According to Torraco (2005), the result of an integrative literature review may be the development of a new framework or the generation of new perspectives about a topic. The same author affirms that it is appropriated for mature and new or emerging topics. In this article, the effort was to integrate a mature topic (internationalization and entry modes) with an emerging one (BMI). We selected papers in a non-systematic way. We started the review through the main literature on BM, followed by a search in several databases as Ebsco, 
BBR

16,3

Elsevier and Proquest, for example. We also looked for the most cited papers on the field. After reading the abstract, we selected those ones that were related with the research.

In the sequence of the article, the concepts of BM, BM design, BMI, and its relationship with internationalization are review with a descriptive approach. The section related with internationalization and entry modes presents the critical analysis that cross this knowledge with the previously presented ones. The elements of a BM proposed by Amit and Zoot (2001) and Zoot and Amit (2010) were used to relate entry modes and the need for a business model innovation in each element. At the same time, the work of Zhang, Zhao and Xu (2015) was used to cross the type of BMI with the entry modes.

\section{BUSINESS ModeL}

BM represents how a firm operates and creates value for its stakeholders (CasadesusMasanell \& Ricart, 2010a). It is more than a logical way to do business (Teece, 2010), it represents a system of interdependent activities with a firm's partners, including how it delivers value to stakeholders (Zoot \& Amit, 2010). As defined by Teece (2010, p. 172), the "essence of a business model is in defining how the enterprise delivers value to customers, entice customers to pay for value and converts those payments to profit". Casadesus and Ricart (2010) argue that a BM represents a set of choices (policies, assets and governance) and consequences (flexibility and rigidity). In addition to different concepts of BM, Schneider and Spieth (2013) state that the common element of these concepts is the fact that no one limits their scopes on a firm's internal elements or external environmental factors. The concept of BM is more of a holistic perspective to understand the activities of a firm.

A BM must be designed to create value through the exploitation of business opportunities (Amit \& Zoot, 2001) which fulfills customers' needs and creates customers surplus while generating profit for local firms and partners (Zoot \& Amit, 2010). It can also be considered a coordinated plan to design strategy through customer interaction, asset configuration and knowledge leverage (Venkatraman \& Henderson, 1998). Other elements include the architecture for products, services, and information flows, as well as the descriptions of the business actors and their roles, including their potential benefits, and the sources of revenue (Timers, 1998).

A BM must reflect the managers' hypothesis related to the customers' needs, how they want to be satisfied and what they will pay for, organizing all these answers in a system capable of giving the customers the best offer and assuring a better return for the company (Teece, 2010). To address the same costumers' needs, or even to pursue similar product market strategies, firms can adopt very different BM. As Zoot and Amit (2008: 1031) highlight "business model design and product market strategy are complement, not substitutes".

The concept of BM emerges from the need of frameworks to create and capture value out of innovative ideas or technological developments that were not able to do it by itself (Chesbrough 2010). Casadesus-Masanell and Zhu (2013) argue that, besides all the interest that the BM subject had attracted over the last few years, it is still a 'slippery' research construct. Spieth, Schneckenberg and Ricart (2014) investigated the literature related to the field. According to them, the papers address one of these three goals: explaining the business; running the business; or developing the business.

As investigated by Schneider and Spieth (2013), three theoretical approaches have been used to explain and support a BM. The first is the Resource-Based View (RBV), which focuses on the heterogeneity between firms to emphasize their unique, imitable, rare 
and non-substitutable resources, which are used as source of competitive advantage. The Dynamic-Capabilities is the second view, which emphasizes the decreasingly lasting character of competitive advantage in volatile environments, as well as the need for companies to re-create themselves and to apply new value creating strategies. The third theoretical approach is the Strategic Entrepreneurship Perspective that allows the consideration of a company's internal initial situation and of external opportunities including an entrepreneurial opportunity-seeking and strategic advantage-seeking as part of the unit of analysis. Based on these approaches, it is possible to highlight that, while the RBV and the Dynamic Capabilities approaches allow the company to identify and adjust aspects to develop a BM, the Strategic Entrepreneurship approach better explains how companies can explore and exploit opportunities to BMI.

\section{Business Model Design}

To design, means to architecture an activity system by which firms do business and capture the essence of the BM (Zoot \& Amit, 2010). Teece (2010) defines some key elements of a BM design: it must capture value from innovation, deliver and capture value from customers at the same time. This must be an "art" as "[T]he chances of good design are greater if entrepreneurs and managers have a deep understanding of user needs, consider multiple alternatives, analyze the value chain thoroughly so as to understand just how to deliver what the customer wants in a cost-effective and timely fashion, adopt a neutrality or relative efficiency perspective to outsourcing decisions, and are good listeners and fast learners" (Teece, 2010: 190).

To design a BM, a company must do a careful strategic analysis to assure that it will lead the company to commercial success, since the lack of analysis may lead the company to failing (Teece, 2010). To address a market opportunity, the firm's managers may need to span across the firm and its boundaries (Zoot \& Amit, 2013) to craft the best design. Sometimes, it may be necessary for managers to expand their perspectives to find an appropriate BM that enables the company to capture the value from technology (Chesbrough, 2010).

According to Amit and Zoot (2001) and Zoot and Amit (2010), a BM has three main components: content, structure, and governance.

- Content is related to how information and goods are exchanged, and to the required resources and capabilities to enable exchanges (Amit \& Zoot, 2001). It represents the selection of activities that are performed (Zoot \& Amit, 2010).

- Structure is related to the network size and the ways in which parties are linked and exchanges are executed, to the order and timing of exchanges, to the market mechanism, and to the flexibility and adaptability of the transaction structure (Amit \& Zoot, 2001). It describes how the activities are linked, meaning the sequence of these activities (Zoot \& Amit, 2010).

- Governance is related to the locus of control of flows of information, goods, and finances. It also includes the nature of control mechanisms, like trust ad incentives (Amit \& Zoot, 2001). It refers to whom performs the activities (Zoot \& Amit, 2010).

To create value through a BM, a firm can adopt a design theme. A design theme is a design configuration of elements or the degree to which they are structured and connected by distinct themes. According to Amit and Zoot (2001), and Zoot and Amit (2010), there are four design themes: novelty; lock-in; complementarities; and efficiency. To summarize the BM design, Zoot and Amit (2010) consider it as an activity system that addresses all vital issues of a business, "and give[s] managers and academics a language and a conceptual 
BBR

16,3

211

toolbox to address them and engage in insightful dialogue and creative design" (Zoot \& Amit, 2010: 222). To develop the investigation about BM and entry modes, the component's structure proposed by Amit and Zoot (2001) and Zoot and Amit (2010) was select as it provides a clear way to understand the concept of BM.

\section{Business Model InNovation}

Competitive environment requires from companies not just addressing customer needs more precisely, but also capturing value by continuously providing new products and services (Teece, 2010). As highlighted by Chesbrough (2010: 356), a company should have "at least as much value to gain from developing an innovative new business model as from developing an innovative new technology"; managers need to develop the capability to innovate their BM. The need for change can be either in response to or in proactive anticipation of exogenous change (Spieth, Schneckenberg, \& Matzler, 2016).

Usually companies innovate their BM when they first create it. However, the need for innovation must be a constant during a company's life to keep the BM viable (Teece, 2010). To innovate their BM, managers must rethink an old model to make it fit for the future (Zoot \& Amit, 2010). The need for innovation becomes greater when 'old' models no longer work, and a BM experimentation turns out to be very important, since only experimentation can help identify and create the data needed to justify a new BM (Chesbrough, 2010).

To innovate in BM, companies need to develop processes that provide high fidelity as quickly and cheaply as possible, aiming to gain cumulative learning from (perhaps) a series of 'failures' before discovering a viable alternative BM (Chesbrough, 2010). It is a continuous and evolutionary process, which focuses on the learning aspects of the process to improve it (Chanal \& Caron-Fasan, 2010).

$\mathrm{BM}$ is a way to deliver a frame to organize value-creation and value-capturing transactions in a company. To innovate, managers need to rethink the customer value proposition to reconfigure the creation value and the value-capturing activities. New BM will provide new opportunities for the company to gain competitive advantages (Spieth, Schneckenberg, $\&$ Matzler, 2016). The continuous BM innovation may include attention to the identification of virtuous cycles in the company actual model. It should also include the identification and correction of any vicious cycles like those generated by BM inconsistencies and those that could become virtuous if supported by appropriated complementary choices. A recommendation proposed by Casadesus-Masanell and Ricart (2010) is to pay attention to act in interaction with other industry players' BM as the business interaction may open opportunities to reconfigure the BM adding value to 'open spaces' where there is little negative interaction with other industry players, as well as to build positive and complementary interactions when possible, and to reduce negative interactions or neutralize them through tactical choices.

Chesbrough (2010) argues that the success of the current BM may influence the managers to keep it, instead of trying a new one. Innovation in business may involve a conflict with more traditional configurations of firm assets (Amit \& Zoot, 2001). Christensen and Raynor (2003) highlight a potential tension because of a conflict between an already established BM and a new one that is required to explore an emerging or disruptive technology. Euchner (2016: 10) calls it the "paradox of BMI - "(...) it should probably be undertaken only when necessary - that is, when the existing business model is hitting its limits - but it must be initiated while that model is still profitable, before there is sufficient discomfort to motivate such wrenching change. That makes implementation tricky".

Emergent opportunities usually lack deep wealth of data to justify company's actions. Chesbrough (2010: 361) emphasizes that "it is only through taking experimental actions that new data will be generated". It does not mean that companies should always take risks 
to innovate their BM, instead, it means that a portion of experimentation is needed to catch the best opportunities to innovate. The simultaneous existence of a traditional BM and a new one may imply in conflicts with functional areas and available resources. The co-existence of theses BM reveals another barrier related to this process: leadership. The lack of leadership may make it impossible to deliver a new better BM for the firm (Chesbrough, 2010). A final barrier is culture. Company's culture must embrace the new model, while keeping the effectiveness of the current one (Chesbrough, 2010).

Considering BMI as the process to optimize and reengineer complex resources, Zhang, Zhao and $\mathrm{Xu}$ (2015) identified three types of BMI:

- Original innovation is related to existing or new companies that offer product or services using a new BM. It can be motivated by the discovery of potential market opportunities and represent an effort to meet these new demands. It can also represent a consequence of new operation processes, including the process of producing and selling products and services, to reduce transaction costs and improve profit, outsourcing, and/or integration.

- Induction innovation is related to external factors that affect one or several elements of the BM, as the changes in the business value system, the changes promoted by a complex economic environment, a dynamic market demand, technology innovation, information flow, and industry evolution.

- Imitation innovation is based on the development of similar successful BM.

\section{Business Model INNOVATION ANd INTERNATIONALIZATION}

Little is known about BMI and internationalization. Rask (2014), for example, presented an interesting critic on Osterwalder's (1994) model stating that it is important to distinguish between domestic and international markets, as Osterwalder's (1994) model does not present any comments about these market differentiations. Rask (2014) argues that the nine points can be separated into two dimensions: the kind of activity - upstream or downstream, and the kind of globalization - globalization of production or of markets. Based on this, he identified four types of international BM with specific strategies and entry mode elements:

- Domestic-based BM: It relies on overcoming differences by taking a standardized strategic approach to domestic demand and supply markets through domestic sales, indirect export, and local production activities;

- Import-based BM: It focuses on domestic markets with a specialized strategic approach through import, contract manufacturing/outsourcing, and production subsidiaries abroad;

- Export-based BM: It focuses on domestic production with an adaptive strategic approach to globalized markets through direct international sales, direct export through agents, and sales subsidiaries abroad;

- Semi-global BM: It relies on the globalization of markets and production with coordination of strategic approaches through licensing, franchising, joint ventures, and sales and production subsidiaries abroad.

Lee, Shin and Park (2012) studied globalization as a driver of BMI. They selected four BM components as relevant keys in emerging markets: offering; strategy; capability; and globalization. As a result, they identified four main business models, which are distinct when regarded their innovativeness: global champion; focused R\&D; global niche market; and global infant. The current paper investigates globalization as a requirement for BMI (Schneider \& Spieth, 2013); however, it does not investigate how globalization influences the innovation process. Indeed, when researching about the elements and the process of 
BBR

16,3

213

BMI, Schneider and Spieth (2013) realized that the already published papers only presented frameworks and hypotheses derived from theoretical explorative research

Through the investigation of a single case study, Landau, Karna and Sailer (2016) found that companies adapt their BM to international markets. The internationalization process was investigated through the analysis of the following components: value proposition (to target a market segment); value creation and delivery; value capture; activity system content; activity system structure; activity system governance; and activity system design theme. They identified the three first ones as the most important in the context of BMI and they used the degree of adjustment in each one to propose a four-phase adaption process to develop a local emerging market BM. The first phase 'International Extension' focuses on adjusting value proposition and value capture. The 'Local Emergence' is the second phase and its focus is on adjusting downstream value delivery. The third is 'Local Expansion' which focuses on adjusting upstream value creation. The 'Local Consolidation' presents equal emphasis on value proposition, creation and delivery, and capture.

Johansson and Abrahamsson (2014) investigated how business models were used and innovated by three born global companies of service to catch new business opportunities. They identified that sensing capabilities, entrepreneurship, and relational capabilities represent the core to manage and to innovate a BM. The companies used the BM concept as a tool to 'navigate' their value chains to achieve international success. Casadesus-Masanell and Ricart (2010) analyzed innovative companies in Catalonia to understand the need for adapting BM to changes in the environment so they could keep their competitiveness. The researchers considered the companies' paths to innovation and internationalization. Each of the investigated companies had followed a different route to it, but they all needed to adapt their BM to remain competitive. The three mains 'lessons' learnt from these companies are: to be alert and take advantage of changes in the environment, to search for robust virtuous cycles and support them with complementary choices, and to focus on virtuous cycles that generate added value. As presented, the linkage of the internationalization through different types of entry modes and the need for BMI is a new study field. To start establishing the connection between the subjects, the next section presents the entry modes and a critical literature review with an analysis considering the literature previously presented in this article, in special the studies by Amit and Zoot (2001), Zoot and Amit (2010) and Zhang, Zhao and $\mathrm{Xu}$ (2015), as we use them as the base for the theoretical model.

\section{Internationalization ANd EnTRY Modes}

Entry modes represent forms of internationalization, and different types of entry modes have been deeply investigated over the last decades. Since we no longer want to investigate entry modes, as our focus relies on the consequences of their adoption on business model, a brief description of the entry modes is presented. To conduct the analysis, each entry mode will be investigated in a separate way. The combination of different types of entry modes at the same moment in any company will lead to different impacts on BMI. As this paper is a first effort to analyze these two subjects, the analysis of each entry mode will be developed based on its own concept and characteristics identified through the literature review. The analysis to integrate entry modes and BMI is all based on the literature review.

Export is the more appropriate entry mode for companies that are internationalizing for the first time and seek to reduce the risks as it requires less commitment from the company (Kotabe \& Helsen, 2000). Usually the company starts selling to the internal market and then starts exporting. An indirect export represents the use of intermediaries to connect the company with customers abroad. The firm begins exporting with low fixed capital 
investments, reduced start-up costs and lower risks (Root, 1994). It has little control over the way its products are sold abroad and, therefore, depends on the intermediary's ability to act in the target market (Kotabe \& Helsen, 2000). Usually companies adopt a very passive approach, as they are still working the same way they operate in their home countries. They just start selling products to companies that export them. Even though this behavior is not mandatory, the use of indirect export represents a way to reduce the need for changing the company's activities. The company can still perform the same activities, and goods and information can still be exchanged the same way: the sale is being made in the internal market. A new client is added into the existing selling process. Considering the need for innovating the company's BM, the need for innovating the content is low. Regarding the structure, the same low need for innovation is identified, as the link between the activities and its sequences does not need to change. The governance, at the same time, also presents a low innovation necessity. One could argue that the intermediary could represent a change in the company's structure and governance. We consider that this change implies modifications in the Supply Chain, not in the company itself. To analyze the BMI, the concept of Zoot and Amit (2010) focuses on a company's internal activities, and on their inter-organizational relations.

The direct export implies a direct contact between the company and its customer. Usually, companies have a department responsible for its sales abroad, which may include traders and operational staff. When companies evolve, they accumulate international experience and market knowledge, usually moving from indirect export to direct export (Johanson \& Vahlne, 1990). Its main advantage is the possibility to obtain information from the external market and feedback from international clients more quickly (Root, 1994). However, it has the disadvantage of higher initial costs, since there is more information to be obtained, and the risks are greater comparing with indirect export (Root, 1994). Nevertheless, direct export usually represents a proactive effort from a company to develop new markets for their products. A company may need to change their production process or even the product to adapt it to an international market. To explore the international market, a company usually does prospective activities to promote its product and to contact potential clients. These are new activities for a company that is used to performing only in a domestic market. Hiring staff or relocating employees is necessary to conduct these activities. The establishment of a department to deal with the export activities is usually identified. To direct export, a company needs to be able to meet customs regulations and to manage the relationship with third-party suppliers. Considering this need for changes, one may affirm that the adoption of direct export leads to a medium level of innovation in a company's BM, taking under consideration its three aspects: content, structure, and governance.

- Proposition 1a: Indirect export will lead to low business model innovations in terms of content, structure, and governance.

- Proposition 1b: Direct export will lead to medium business model innovations in terms of content, structure, and governance.

- Proposition 1c: Considering exports, business model innovations will be more related to induction and imitation.

Direct and Indirect export can be related to the "Export-based BM" proposed by Rask (2014). The second type related to the international environment is the "Semi-global BM", which is related to Contractual agreements that include different forms of entry modes like strategic alliances, joint venture (JV), licensing, and franchising. 
BBR

16,3

Strategic alliances represent forms of partnership between two or more companies, with the purpose of carrying out joint projects or of cooperating in a single market (Porter, 1991). Companies explore the benefits of new opportunities together, as well as sharing costs and minimizing risks, thus generating a competitive advantage for everyone involved (Kotabe \& Helsen, 2000). They arise from the necessity of complementation of resources and capabilities, since not all of them have the necessary elements for international operations (Hamel \& Prahalad, 1995). Alliances represent a facilitated way to enter international markets, while physical resources, knowledge, and skills are shared, these can be incorporated into already existing competences in the firm to take advantage of the opportunities of various markets (national and international) (Hamel \& Prahalad, 1995; Hitt; Ireland, \& Hoskisson, 2008). For Teece (1992), a strategic alliance requires a certain degree of strategic and operational coordination of activities and should consider, among other elements, research and development activities, technology transfer, granting of production rights, and the cooperation agreements between the companies involved in the partnership. A JV is a strategic alliance, even though some conceptual models consider it as a different type of contractual agreement.

A JV is a form of cooperation between independent companies, in which a joint project is carried out with fixed time and shared risks. It is the appropriate entry mode for companies that want to transfer imitable and substitutable resources (Kogut \& Zander, 1993). Among the disadvantages of a JV, it is possible to point out the high cost incurred by the company due to the control and coordination of partners involved (Keegan \& Green, 2000). Another challenge is the possible cultural difference between the partners, their activities and managerial styles. In addition, many companies end their JV agreements when partners see themselves as competitors (Keegan \& Green, 2000).

Licensing is the contractual agreement in which a company, called a licensor, provides a good patent, name of a company, technology or any business information to another company (licensed). Through a licensing agreement, it is possible for a foreign company to buy the right to manufacture and sell products from another firm in a host country. Thus, for each unit produced and sold, a royalty or licensing fee is paid to the licensor. On the other hand, the licensee invests in facilities for the manufacture, distribution and sale of goods and services, also taking the risks involved. It is ideal for companies that present advanced technology, high know-how or a strong and consolidated brand in the market; therefore, obtaining greater profitability without a high initial investment (Keegan \& Green, 2000: Davidson \& McFetridge, 1984). It also brings benefits to products that require physical adaptation to the target market, since part of the cost can be transferred to the foreign licensee (Root, 1994). The disadvantages can be the lack of control of the firms, which manufacture and advertise their products in foreign countries, and smaller returns, considering that profit is distributed between the licensee and the licensor (Hitt, Ireland, \& Hoskisson, 2008). In addition, when the licensee develops their own know-how, they become a competitor of the licensor, thus representing a threat and a general disadvantage of that entry mode (Kotabe \& Helsen, 2000).

Franchising is a contract agreement between a franchisor that allows a company (franchisee) to use the name of the company and to receive assistance from the franchisor in general aspects of company, such as management and marketing, through the payment of fees and royalties to the franchisor. It is appropriate for companies that have a high internationalization capacity but whose managers cannot, or do not want to, make efforts to go abroad. The main advantages of a franchise include fast insertion and expansion in international markets, standardized marketing method with an already consolidated image, 
highly motivated franchisees, and reduced political risks (Root, 1994). Kotabe and Helsen (2000) point out that regarding the establishment of franchises, a low investment is necessary to expand the business abroad. Its disadvantages include the restriction on the profit of the franchisor, the lack of total control over the operation of the franchise, the possibility of creating competitors, and the restrictions on contracts imposed by governments (Root, 1994; Kotabe \& Helsen, 2000).

Contractual agreements represent ways to internationalize with lower effort from the company. The higher effort is related to the source of the partner and the establishment of a contract that allows this partnership to be developed while it protects the company from related risks. Considering this, it is possible to state that a high investment in terms of governance is necessary. Contractual agreements include changing the actors that perform the activities. In a JV, for example, a third company is created to perform it. In a Franchising, the efforts of sales, for example, may be transferred to the partner. Looking at this second agreement, we can also identify that the flow of information, goods and finance will be modified as the customer buys a product from the franchisee. Innovations in terms of governance in the company's BM will be required. Innovations in terms of content and structure are low when a company that is starting to operate abroad is considered. In its home country, the company can keep operating the same way it used to do before, since the contractual agreement only applies to the company's international activities. A different situation may be identified if we look at companies that already operated abroad and change their models to a contractual agreement. Considering the subject of this study, the first situation will be focused on;

- Proposition 2a: Contractual agreements will lead to low business model innovations in terms of content and structure, and high business model innovation in terms of governance.

- Proposition 2b: Considering contractual agreements, the business model innovations will be more related to induction and imitation.

Foreign Direct Investment (FDI) consists of territorial expansion of business activities, without being subject to the same conditions of domestic investment. In addition to high risks, it allows local learning and access to external partner knowledge (Dunning, 1973). It also allows the control over an economic activity of transformation or production of goods and services, resulting, in most cases, on the implantation of a physical unit in the target country (Hymer, 1960). There are different forms of FDI as subsidiaries, merges and acquisitions (M\&A), and greenfield operations.

The establishment of a subsidiary requires greater commitment (of capital and labor) by the company that wishes to internationalize. The control over a subsidiary may be total or partial, according to the interest of the organization, and the barriers and legislation of the target country (Keegan \& Green, 2000). Subsidiaries are relevant to organizations that wish to concentrate the control of the operations in the main company and leave to the investor the control of the operations in this company (Kotabe \& Helsen, 2000; Johanson \& Vahlne, 1990). A transfer of knowledge, technologies, and manufacturing techniques between the national company and the one inserted in the target market occurs (Keegan \& Green, 2000). The disadvantage is that it is not possible to share risks because all liabilities are concentrated in the main company (Brouthers \& Hennart, 2007). Another limitation is the lack of partnerships, since the resources used are greater than in other entry modes (Kotabe \& 
Helsen, 2000). There are two possibilities of subsidiaries owned by the main company: acquisition; or greenfield, (Kotabe \& Helsen, 2000).

Acquisitions consist of companies or groups of investors that buy the equity or share control of another company and have the advantage of allowing the company to enter established relationships in the target country, and to enter the local market immediately (Porter, 1991). It allows rapid access to international markets, local technologies, and brands already consolidated in the target market. It also combines resources of the new entrant with the ones of the acquired company (Meyer \& Peng, 2005; Kotabe \& Helsen, 2000) and it is a less expensive internationalization alternative (Keegan \& Green, 2000). The acquisition represents a high investment for the company's international strategy, since, for the most part, the promising companies are not for sale, and if they are, their value is very high (Kotabe \& Helsen, 2000). More efficient markets usually facilitate the entry of new companies by the acquisition (Meyer et al, 2009).

Mergers are entry modes that are characterized as alternatives for the adequacy of the size and organizational structure of the companies to the market and to the world's economic scenario (Matias \& Pasin, 2001). They usually occur among firms that have equivalent dimensions, making the original company disappear and creating a new one, which results from the union of the material and human assets of the organizations involved in the business (Matias \& Pasin, 2001). It allows companies to save in a production scale, to achieve greater market power, to diversify risks (since the company operates in several countries and is less vulnerable to local crises), and above all, to enter new markets and new industries faster (Samuels \& Wilkers, 1996).

Greenfield are characterized by complete operations, established from the beginning. It presents greater flexibility in human resources, supplies, logistics, factory layout, and technology (Kotabe \& Helsen, 2000). A greenfield project does not allow direct access to existing resources in the foreign company, but it allows the entrant to purchase resources available in the local markets (Meyer et al., 2009). Some governments in foreign countries offer incentives and benefit packages for companies that install full operations in that region, aiming at establishing greater market attractiveness. On the other hand, this operation requires high investment of time and capital (Kotabe \& Helsen, 2000). In general, companies with diverse product lines prefer to enter a new market through acquisitions, other than those with a specific product line, which opt to do it through greenfield (Brouthers \& Brouthers, 2000). FDI and its different forms are not explored at Rask's (2014) model.

Analyzing the use of FDI as an internationalization strategy, one can realize that it implies a high level of BMI considering the three main elements: content, structure, and governance. Considering the model proposed by Zhang, Zhao, and Xu (2015), this entry mode can be related more to original innovation, as the company is promoting changes in their

Figure 1 - Entry modes, elements of a BM and types of BMI

\begin{tabular}{|c|c|c|c|c|c|}
\hline & & \multicolumn{3}{|c|}{$\begin{array}{l}\text { Elements of a BM (Amit \& Zoot, 2001; Zoot \& Amit, } \\
\text { 2010) }\end{array}$} & \multirow[t]{2}{*}{$\begin{array}{l}\text { Type of BMI (Zhang, Zhao \& } \\
\text { Xu, 2015) }\end{array}$} \\
\hline \multicolumn{2}{|c|}{ Type of entry mode } & Content & Structure & Governance & \\
\hline \multirow[t]{2}{*}{ Export } & Indirect export & Low & Low & Low & \multirow{2}{*}{$\begin{array}{l}\text { More related with induction } \\
\text { and imitation }\end{array}$} \\
\hline & Direct export & Medium & Medium & Medium & \\
\hline \multirow{4}{*}{$\begin{array}{l}\text { Contractual } \\
\text { Agreements }\end{array}$} & Strategic alliance & Low & Low & High & \multirow{4}{*}{$\begin{array}{l}\text { More related to induction and } \\
\text { imitation }\end{array}$} \\
\hline & Joint Venture & Low & Low & High & \\
\hline & Licensing & Low & Low & High & \\
\hline & Franchising & Low & Low & High & \\
\hline \multirow[t]{4}{*}{ FDI } & Subsidiary & High & High & High & \multirow{4}{*}{$\begin{array}{l}\text { More related to original } \\
\text { innovation }\end{array}$} \\
\hline & Acquisition & High & High & High & \\
\hline & Merges & High & High & High & \\
\hline & Greenfield & High & High & High & \\
\hline
\end{tabular}


global value chain with the opening of a new unit. BMI related to the previous entry modes tend to be more of a result of an induction and/or imitation.

- Proposition 3a: FDI will lead to high business model innovations in terms of content, structure, and governance.

- Proposition 3b: Considering FDI, the business model innovations will be more related to original innovation.

Figure 1 presents the consolidation of the analysis of entry modes, as well as the level and type of business model innovation.

\section{FinAL CONSIDERATIONS}

This article presents a theoretical investigation of the construct 'BMI' and the internationalization process of a firm based on entry modes. Based on literature review, we identified that little is known about the relation between these two subjects. Some research projects on BMI already consider the international environment, to our knowledge, until this date, no one had already established a relation with entry modes. Taking this gap under consideration, we wrote a literature review about entry modes. This review focused on the analysis of the confrontation of entry modes with the main concept of BM and its elements developed by Amit and Zoot (2001) and Zoot and Amit (2010). Considering three elements, the potential level of impact in the need for innovation that each entry mode may generate in a company was identified. At the same time, Zhang, Zhao and Xu's (2015) model was used to relate the types of entry modes and the type of BMI. Exports and contractual agreements appeared to be more related to induction and imitation, and FDI to original innovation.

Considering the lack of applied research focusing on this subject, this research was conducted to develop some propositions that could lead to an exploratory research. This paper is restricted to the lack of previous research, but the development of a theoretical basic model to start the discussion about the relation of BMI and entry modes was necessary. Empirical investigation is required for advancement in the study of these fields of knowledge. We suggest the development of some case studies focusing on the analysis of the internationalization process and the impacts of it on its BM. Like a previous research on this, we have already investigated some papers on case studies that present internationalization process and we have identified that most of them do not present all the required information to be used as a complete base for this kind of investigation. The main reason is that the concept of $\mathrm{BM}$ was not included as an investigation variable and parts of the required information might not be well investigated. Because of that, some case studies as an exploratory investigation are recommended. Even though a survey is a very important research method that allow us to investigate a broader number of companies, we were not able to identify in literature a consistent base of knowledge to identify the variables to be investigated in a deeper investigation model. More research is required to identify these variables. Most of the papers on BM and BMI are theoretical or case studies investigations of technology-based companies or start-ups. Little is known about these innovations in more mature industries.

Other future studies recommendations regard the analysis of the variables that could influence the BMI, as the nature of the industry and the product. The adoption of different entry modes at the same time could imply in different impacts. In this paper, each entry mode was isolated as we consider each concept when investigating the level of impact on BM elements and the type of BMI. A study of a company that adopts different entry modes may lead to the understanding of these relationships. The identification of the variables that will 
influence the impact on the elements of a BM as a consequence of the internationalization process may represent a first effort on this recommendation.

From an academic point of view, one must consider that the propositions presented in this paper and the theoretical model should be viewed as future research guidelines. They cannot be considered as replicable results. Our effort was to integrate the discussion about BMI and internationalization through different entry modes, as there was a gap related with the connection of these topics. The use of the knowledge presented in this paper will support the improvement of the two research fields. From an executive perspective, the results may be used as a way to understand that the internationalization implies on a company's $\mathrm{BM}$, and the need of innovation may not only be related with products and services, but also with the business as a whole. BMI can be a consequence of the international exposure of the firm and the understanding of the different elements of and types innovation can lead to a better strategy that assure competitiveness.

This article discussion, propositions, and model start explaining how the internationalization of a firm will lead to BMI decomposing it by its elements and types. It represents the first effort aiming at analyzing the need for a business model innovation as a consequence of the internationalization process through the adoption of different entry modes, thus, more research is required.

\section{REFERENCES}

AMIT, R.; ZOOT, C. Value creation in e-business. Strategic Management Journal, v. 22, p. 493-520, 2001. BROUTHERS, K. D.; BROUTHERS, L. E. Acquisition or greenfield start-up? Institutional, cultural and transaction cost influences. Strategic Management Journal, v. 21, n. 1, p. 89-97, 2000.

BROUTHERS. K.D.; HENNART. Boundaries of the Firm: Insights from international entry mode research. Journal of Management, v. 33, n. 3, p. 395-425, 2007.

CASADESUS-MASANELL, R.; RICART, J.E. Competitiveness: business model reconfiguration for innovation and internationalization. Management Research: The Journal of the Iberoamerican Academy Management, v. 8, n. 2, p. 123-149, 2010.

CASADESUS-MASANELL, R.; ZHU, F. Strategies to fight ad-sponsored rivals. Management Science, v. 56, n. 9, p. 1484-1499, 2010.

CASADESUS-MASANELL, R.; RICART, J.E. From strategy to business models and onto tactics. Long Range Planning, v. 43, n. 2, p. 195-215, 2010a.

CHANAL, V.; CARON-FASAN, M.L. The difficulties involved in developing business models open innovation communities: the case of a crowdsourcing platform. M@n@gment, v. 13, n. 4, p. 318-340, 2010.

CHESBROUGH, H. Business Model Innovation: Opportunities and Barriers. Long Range Planning, v. 43, n. 2, p. 354-363, 2010.

CHESBROUGH, H. Business Model Innovation: It's not just about technology anymore. Strategy and Leadership, v. 13, n. 4, p. 318-341, 2007.

CHESBROUGH, H.; ROSENBLOOM, R.S. The role of the business model un capturing value from innovation: evidence from Xerox Corporation's technology spin-off companies. Industrial and Corporate Change, v. 11, n. 3, p. 529-555, 2002.

CHRISTENSEN, C.; RAYNOR, M. The Innovator's Solution. Cambridge, MA: Harvard Business School Press, 2003.

DAVIDSON, W. H.; MCFETRIDGE, D. G. International technology transaction and the theory of the firm. The Journal of Industrial Economics, v. 32, n. 3, p. 253-264, 1984.

DEMIL, B. et al. Introduction to the SEJ special issue on business models: business models within the domain of strategic entrepreneurship. Strategic Entrepreneurship Journal, v. 9, n. 1, p. 1-11, 2015.

DUNNING, J.H. The Determinants of International Production. Oxford Economic Papers, v. 25, n. 3, p. 289-336, 1973.

EUCHNER, J. Business Model Innovation. Research Technology Management, v. 59, n. 3, p. 10-11, 2016.

HAMEL, G.; PRAHALAD, C. K. Competindo pelo Futuro: estratégias inovadoras para obter o controle do seu setor e criar os mercados de amanhã. Rio de Janeiro: Campus, 1995. 378 p. 
HAMEL, G.; VALIKANGAS, L. The quest for resilience. Harvard Business Review, v. 81, n. 9, p. 52-63, 2003.

HITT, M.; IRELAND, R.; HOSKISSON, R. Administração Estratégica. 2. ed. São Paulo: Cengage Learning, 2008. $415 \mathrm{p}$.

HYMER, S. The international operations of National Firms: A study of direct foreign investment. Cambridge, MA: MIT Press, 1960.

JOHANSON, J.; VAHLNE, J. E. The mechanism of internationalization. International. Marketing Review, v. 7, n. 4, p. 11-24, 1990.

JOHANSSON, M.; ABRAHAMSSON, J.T. Competing with the use of business model innovation - An exploratory case study of the journey of born global firms. Journal of Business Models, v. 2, n. 1, p. 33-55, 2014.

KEEGAN, W.J.; GREEN, M.C. Princípios de Marketing Global. São Paulo: Ed. Saraiva, 2000.

KOGUT, B.; ZANDER, I. Knowledge of the firm and the evolutionary theory of the

multinational corporation. Journal of International Business Studies, v. 24, n. 4, p. 625-645, 1993.

KOTABE, M.; HELSEN, K. Administração de Marketing Global. São Paulo: Atlas, 2000. 709 p.

LANDAU C.; KARNA, A.; SAILER, M. Business model adaption for emerging markets: a case study of a German automobile manufacturer in India. R\&D Management, v. 46, n. 3, p. 480-503, 2016.

LEE, Y.; SHIN, J.; PARK, Y. The changing pattern of SME's innovativeness through business model globalization. Technological Forecasting and Social Change, v. 79, n. 5, p. 832-842, 2012.

MATIAS, A.B.; PASIN, E.M. A geração de sinergias e seus impactos na rentabilidade das empresas nos casos de fusões e aquisições. Revista de Administração RAUSP, v. 36, n. 1, p. 5-13, 2001.

MEYER, K. et al. Institutions, Resources, and Entry Strategies in Emerging Economies. Strategic Management Journal, v. 30, n. 1, p. 61-80, 2009.

MEYER, K. E.; PENG, M. W. Probing theoretically into Central and Eastern Europe: transactions, resources, and institutions. Journal of International Business Studies, v. 36, n. 6, p. 600-621, 2005.

OSTERWALDER, A. The Business Model Ontology: A Proposition in the Design Science Approach, unpublished dissertation, University of Lausanne. 2004.

POHLE, G.; CHAPMAN, M. IBM's global CEO report 2006: Business model innovation matters. Strategy and Leadership, v. 34, n. 5, p. 34-40, 2006.

PORTER, M. E. Estratégia competitiva: técnicas para análise de indústrias e da concorrência. Rio de Janeiro: Campus, 1991. 409 p.

RASK, M. Internationalization through business model innovation: in search of relevant design dimensions and elements. Journal of International Entrepreneurship, v. 12, n. 2, p. 146-161, 2014.

ROOT, F. Entry Strategies for International Markets. Lexington: Lexington Books, 1994.

SAMUELS, J.M.; WILKES, F.M. Management of company finance. London: International Thompson Business Press, 1996.

SCHNEIDER, S.; SPIETH, P. Business Model Innovation: Towards an integrated future research agenda. International Journal of Innovation Management, v. 17, n. 1, (34 pages), 2013.

SPIETH, P.; SCHNECKENBERG, D.; MATZLER, K. Exploring the linkage between business model (\&) innovation and the strategy of the firm. R\&D Management, v. 46, n. 3, p. 403-413, 2016.

SPIETH, P.; SCHNECKENBERG, D.; RICART, J.E. Business Model Innovation - State of the art and future challenges for the field. R\&D Management, v. 44, n. 3, p. 237-247, 2014.

TEECE, D.J. Business Models, Business Strategy and Innovation. Long Range Planning, v. 43, n. 2-3, p. 172-194, 2010.

TEECE, D. J. Competition, cooperation, and innovation: organizational arrangements for regimes of rapid technological progress. Journal of Economic Behavior and Organization, v. 18, n. 1, p. 1-25, 1992.

TIMERS, P. Business models for electronic markets. Electronic Markets, v. 8, n. 2, p. 3-8, 1998.

TORRACO, R. Writing integrative literature reviews: guidelines and examples. Human Resource Development, v. 4, n. 3, p. 356-367, 2005.

VENKATRAMAN, N.; HENDERSON, J.C. Real strategies for virtual organizing. Sloan Management Review, v. 40 (Fall), p. 33-48, 1998.

ZHANG, Y.; ZHAO, S.; XU, X. Business model innovation: an integrated approach based on elements and functions. Information Technology and Management, v. 17, n. 3, p. 303-310, 2015.

ZOTT, C.; AMIT, R. The business model: A theoretically anchored robust construct for strategic analysis. Strategic Organization, v. 11, n. 4, p. 403-411, 2013. 
ZOTT, C.; AMIT, R. Business Model Design: An Activity System Perspective. Long Range Planning, v. 43, p. 216-226, 2010.

ZOOT, C.; AMIT, R. The fit between product market strategy and business model: Implications for firm performance. Strategic Management Journal, v. 29, p. 1-26, 2008. of Management, v. 37, n. 4, p. 1019-1042, 2011. 